\title{
Bacterias y virus que colaboran
}

La microbiología se convierte en la base de futuras investigaciones sobre la evolución del planeta o la secuenciación del genoma humano

\section{Borja G. Moya}

"El problema de las bacterias es que sólo las notamos cuando nos hacen daño. Las películas, los medios de comunicación y la cultura en general nos han llevado a ver los microbios como algo exclusivamente peligroso. Sin embargo, si el número de especies bacterianas en total fuera de unos 30 millones, apenas 300 serían patógenas", asegura Manuel Sánchez, profesor en el Departamento de Producción Vegetal y Microbiología de la UMH.

El objetivo de su docencia es dar a conocer la importancia de la investigación en el campo de la microbiología, una rama de la ciencia muy útil en el largo plazo pero cuyos resultados a menudo son ignorados por la falta de aplicaciones inmediatas.

Sin embargo, la elaboración de combustibles, la minería, la producción textil o la ecología microbiana constituyen campos de la investigación que en su parte inicial y más básica dependen de cómo avance la microbiología. Esta última rama, la de la ecología microbiana, supondrá, según Manuel Sánchez, una verdadera revolución: "Una gota de agua de mar está llena de microorganismos y son éstos los que hacen posible la vida en la tierra. Entender cómo la acción del ser humano repercute en estos

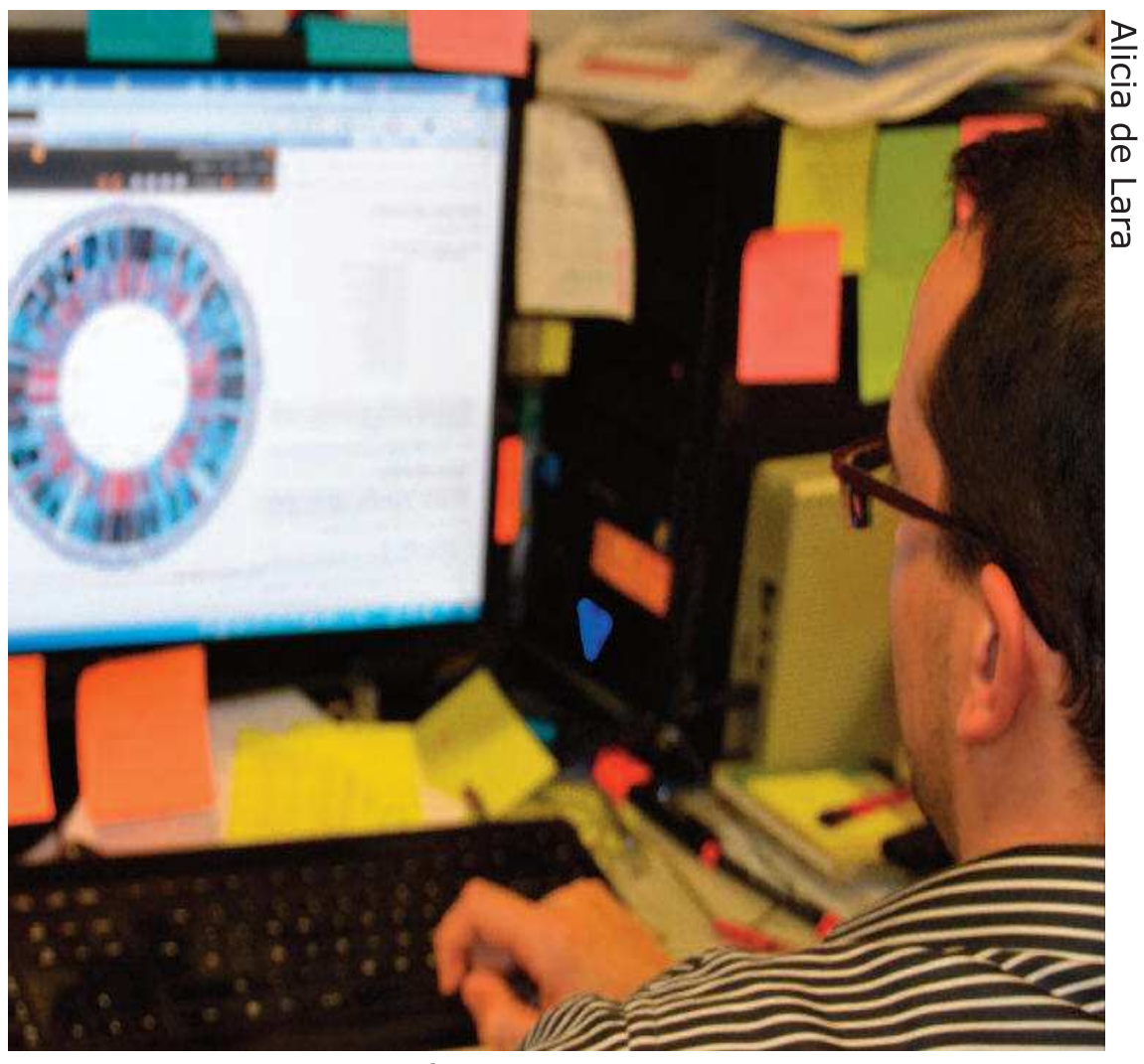

Proceso de secuenciación del genoma de una bacteria marina

microorganismos puede dar pistas sobre cómo va a evolucionar el medio ambiente en los próximos años".

Rodríguez Valera: "La investigación aplicada sólo puede salir de una buena investigación básica"

Precisamente el agua, desde el mar Mediterráneo hasta las aguas del Amazonas, pasando por las salinas de Santa Pola, es el entorno en el que investiga el Evolutionary Genomics Group
(EGG), el grupo de investigación de la UMH encabezado por Francisco Rodríguez Valera. Mediante el empleo de sistemas metagenómicos, el grupo estudia la secuenciación del genoma de los diversos tipos de bacterias que se encuentran en un mar determinado. EI EGG traduce el lenguaje de millones de bacterias marinas y acuáticas para hacerlo comprensible a los seres humanos.

Aunque los resultados en el campo de la microbiología no son inmediatos, el grupo de investigación de Rodríguez Valera emplea el mismo nivel tecnológico que se utiliza para la secuenciación del 
genoma humano, lo que supondrá que en un futuro el personal esté plenamente capacitado para trabajar en este campo. "El simple hecho de ejercitar este tipo de formas de entender los problemas ya es útil porque será el caballo de batalla de toda la tecnología del siglo XXI", asegura el investigador.

No obstante, para el profesor este tipo de investigaciones requiere sobre todo de mucha paciencia, ya que la visión de que todo el mundo tiene que llevar a cabo investigación aplicada es "muy equivocada" porque la ciencia no funciona así. "La investigación aplicada sólo puede salir de un punto donde hay muy buena investigación básica. En el siglo XVIII la electricidad era investigación básica y no se sabía cuál sería su aplicación final", asegura el docente.

\section{Bacterias y alarmismo social}

A pesar de los resultados positivos de las investigaciones en microbiología, todavía hoy continúa la percepción social de que hablar de microbios es sinónimo de hablar de enfermedades. Basta para darse cuenta con pensar en algunos de los temas más difundidos sobre bacterias. La Escherichia Coli (conocida como E.coli), causante de una crisis alimentaria durante el verano de 2011, o el famoso aunque ya olvidado ataque bioterrorista con esporas del microorganismo causante del carbunco o ántrax, que provocó un pánico generalizado a abrir sobres en Estados Unidos. Según Manuel Sánchez, gran parte de la culpa de esta percepción la tienen los medios de comunicación, que acostumbran a reproducir únicamente las noticias malas que "causan alarmismo", pero "no reproducirían noticias que hablaran de que una bacteria determinada ayuda a depurar el agua".
Además de investigador, hace más de cuatro años Manuel Sánchez se lanzó al mundo de la comunicación y decidió poner en marcha su blog Curiosidades de la microbiología, con una sencilla premisa: "Hablar de ciencia como si lo tuviera que entender $\mathrm{mi}$ abuela". Así despierta el profesor el interés entre sus alumnos de primero de carrera que, recién salidos del bachillerato, se enfrentan al estudio de los virus y las bacterias.

Su objetivo es huir de las clásicas diapositivas y optar por las curiosi- dades, las anécdotas y las historias Ilamativas. Precisamente porque para Manuel Sánchez otra de las principales causas de esta incultura científica es el modelo educativo: "Creemos que la cultura es sólo hablar de humanidades y no entendemos que cultura es también saber qué es la Ley de la Gravedad, o qué significa la Evolución o la termodinámica". Y sentencia: "Tan importante es que un alumno conozca el Quijote como la primera Ley de Newton, aunque por lo visto ser un analfabeto científico no parece ser un problema".

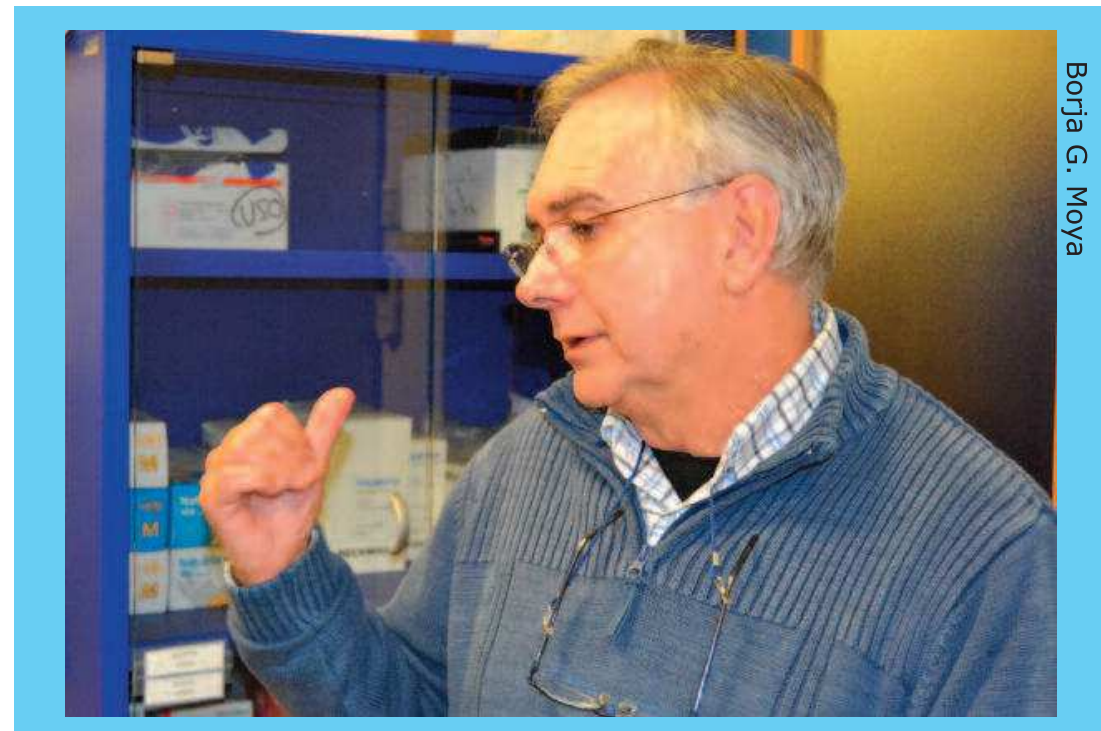

Rodríguez Valera en el campus de Sant Joan

\section{Recortes, reducciones y tendencias cortoplacistas}

- Borja G. Moya

Si en algo coinciden los investigadores Manuel Sánchez y Rodríguez Valera, además de en la microbiología, es que la actual política de recortes en ciencia dificulta cada vez más sus investigaciones. En este sentido, Manuel Sánchez considera que si algo ha caracterizado a España desde la transición es el carácter "cortoplacista" de sus inversiones, que "siempre han buscado resultados inmediatos cuando lo que se tendría que haber hecho era invertir en el largo plazo".
Según el investigador, no es de extrañar la "fuga de cerebros" que se está produciendo en el campo de la ciencia, por la que multitud de investigadores emigran por falta de recursos.

Además, Rodríguez Valera critica que "en España se ha despilfarrado dinero en ciencia de manera lastimosa". Según el investigador y docente, la solución pasa porque los políticos entiendan la importancia de la ciencia y para ello debe invertirse el presupuesto "bien y con sensatez". 